\title{
The Existence and Legal Problems of Pak Ogah in Indonesia
}

\author{
Adhi Putra Satria
}

Universitas 17 Agustus 1945 Semarang, Indonesia,

Email: putraadhisatria1@gmail.com

\begin{tabular}{|c|c|}
\hline Article Info & Abstract \\
\hline $\begin{array}{l}\text { Keywords: } \\
\text { Legal Guarantee, Safety, Pak } \\
\text { Ogah, Legal Protection } \\
\text { How to cite: } \\
\text { Adhi Putra Satria, "The Existence } \\
\text { and Legal Problems of Pak Ogah } \\
\text { in Indonesia," Fiat Justisia: Jurnal } \\
\text { Ilmu Hukum 14, No. 1 (2020): 33- } \\
\text { 44. } \\
\text { 10.25041/fiatjustisia.v14no1.1770 }\end{array}$ & $\begin{array}{l}\text { Pak Ogah is a citizen, either an individual or a } \\
\text { group that participates in regulating traffic order } \\
\text { in the hope of being rewarded by road users who } \\
\text { will pass or turn around at intersections in major } \\
\text { cities in Indonesia. In this study, the issues will be } \\
\text { presented that factors influence the emergence of } \\
\text { Pak Ogah, and what legal problems arise from the } \\
\text { phenomenon. The method used in this study is a } \\
\text { qualitative research method with a juridical- } \\
\text { empirical approach which uses facts in the field as } \\
\text { the primary data. The results of the study stated } \\
\text { that the emergence of the phenomenon of Pak Ogah } \\
\text { was caused by three main factors, namely the legal } \\
\text { substance, legal structure (law enforcement } \\
\text { officers), and the legal culture of the Indonesian } \\
\text { people. Furthermore, the problem arising from the } \\
\text { phenomenon is that there is no legal guarantee and } \\
\text { work safety for the protection of Pak Ogah if an } \\
\text { accident occurs when regulating traffic order. }\end{array}$ \\
\hline
\end{tabular}

\section{A. Introduction}

Prosperity is a necessity for humans in living their lives. Humans always make efforts that can lead it into a prosperous life. The efforts that are carried out need to have limits. It is intended so that the efforts to meet their welfare always in the right corridor and not violating the human rights of other individuals that have been mutually agreed upon in social life. Today, the state has a vital role in ensuring the welfare of its citizens. Miriam Budiardjo argues that the idea of a government prohibited from meddling in the affairs of its citizens has turned into an idea of a government that is responsible for the welfare of its people. This is lead to the consequences of a government that must be active in regulating economic 
and social life. It is intended so that the state minimizes the differences/gaps in the economic and social area in society. ${ }^{1}$

In regards to the role of the state in regulating people's lives, Adam Smith has his views. As quoted by Ebenstein in Muryanto Amin's states that there are three tasks of the state in society. First is the duty of the state in the field of defence. Second, the duty of the state to protect every individual in society to fight injustice and oppression caused by other members of the community by ensuring impartial security. Third, the duty of the state to build infrastructures such as maintaining public works and useful public institutions, not for the benefit of a particular individual or group of people. ${ }^{2}$

In the context of the Unitary State of the Republic of Indonesia, welfare for all Indonesian people is the goal of an independent Indonesia that has been mentioned in the Preamble of the 1945 Constitution of the Republic of Indonesia (URI NRI 1945) Paragraph IV which states that the purpose of an independent Indonesia is to include: ${ }^{3}$

1. Protect all the people of Indonesia and the entire homeland of Indonesia;

2. Improve the public welfare;

3. Advance the intellectual life of the people; and

4. Contribute to the establishment of a world order based on freedom, abiding peace, and social justice.

To achieve these goals, the respect for human rights of the citizens needs to be guaranteed. It is in line with the principles of the rule of law which implies that it requires the recognition of human rights guarantees in the Constitution. ${ }^{4}$

Our constitution has guaranteed the existence of the human rights of Indonesian citizens. These rights are contained in the 1945 Constitution of the Republic of Indonesia Article 27 to 28J. In principle, there are three categories of regulation concerning the rights of the Indonesian people contained in the 1945 Constitution of the Republic of Indonesia. Three categories of the regulation are the regulation of basic norms for individual community rights, the regulation of basic norms for collective community rights, and the regulation of basic norms of rights for children. ${ }^{5}$

The Republic of Indonesia has also given people access to social security which is part of human rights and has been regulated in Article 27

\footnotetext{
${ }^{1}$ Ridwan HR, Hukum Administrasi Negara (Jakarta: Rajawali Pers, 2011), 59.

${ }^{2}$ Muryanto Amin, "Konsep Negara Kesejahteraan dari Waktu ke Waktu," POLITEIA 3, No. 2 (2011): 106.

${ }^{3}$ See the Preamble of the 1945 Constitution of the Republic of Indonesia.

4 Zulkarnain Ridlwan, "Negara Hukum Indonesia Kebalikan Nachtwachterstaat," Fiat $\begin{array}{lllllll}\text { Justisia: Jurnal Ilmu Hukum 5, } & \text { No. } 2 & \text { (2012): } & 143 .\end{array}$ https://doi.org/10.25041/fiatjustisia.v5no2.56.

${ }^{5}$ Encik Muhamad Fauzan, "Fungsi Sosiologis UUD 45 dalam Memenuhi Hak-Hak Dalam Masayarakat," Jurnal Masalah-Masalah Hukum 42, No. 3 (2013): 106. 
paragraph (2) and Article 28H paragraph (3) of the second amendment of 1945 Constitution. Article 27 paragraph (2) formulates that: "Every citizen has the right to work and a decent living of humanity", while Article $28 \mathrm{H}$ paragraph (3) of the second amendment of 1945 Constitution formulates: "Every person has the right to social security that enables the development of themselves as a dignified human being". ${ }^{6}$

Departing from the regulation of human rights in the Indonesian constitution, there are human rights that guarantee the protection and legal certainty owned by the community. It is regulated in article $28 \mathrm{D}$ paragraph 1 of the 1945 Constitution of the Republic of Indonesia which states that Indonesian citizen has the right of recognition, guarantee, protection, and legal certainty that is just and equal treatment before the law. ${ }^{7}$

There are several works of literature that provide concepts and understandings of the meaning of legal protection. Satjipto Rahardjo, for example, believes that legal protection is an umbrella for human rights harmed by others. Protection is given to the community so that people can enjoy all the rights granted by law. ${ }^{8}$ Muchsin, ${ }^{9}$ on the other hand, argues that legal protection is an effort that protects legal subjects through applicable laws and regulations and has been determined to be implemented. Legal protection can be divided into two, namely: Preventive Legal Protection, which is a protection provided by the government to prevent violations. It is contained in legislation with the intent to avoid a violation and provide limitations in carrying out obligations and repressive legal protection. Repressive legal protection is the final protection in the form of sanctions such as fines, imprisonment, and additional penalties given if a dispute has occurred or if a violation has been committed.

Nowadays, a number of factors can influence a human's lives in society. The four main factors that are the strongest and most dominant in affecting human's lives are cultural factors, legal factors, political factors, and economic factors. These four factors, economic factors are the most powerful and dominant in influencing human's lives and ways of behaving in society in achieving their welfare, as in the case of Pak Ogah. Pak Ogah is a citizen either an individual or in a group that helps regulate the traffic order in the hope of being rewarded by road users who will cross or turn around at intersections in major cities. The emergence of Pak Ogah phenomenon

6 Dede Agus, "Perkembangan Pengaturan Jaminan Sosial Tenaga Kerja Dalam Rangka Perlindungan Hukum Buruh/Pekerja," Fiat Justisia: Jurnal Ilmu Hukum 8, No. 1 (2014): 5556. https://doi.org/10.25041/fiatjustisia.v8no1.286.

${ }^{7}$ Solidman Bertho Plaituka, "Constitusional Complaint Dalam Rangka Penegakan Hak Asasi Manusia di Republik Indonesia," Jurnal Media Hukum 23, No. 1 (2016): 110-120.

${ }^{8}$ Satjipto Raharjo, Ilmu Hukum (Bandung: Citra Aditya Bakti, 2000), 74.

${ }^{9}$ Dyah Permata Budi Asri, "Perlindungan Hukum Preventif Ekspresi Budaya Tradisional di Daerah Istimewa Yogyakarta Berdasarkan Undang-Undang No 28 tahun 2014 Tentang Hak Cipta," Journal of Intelectual Property 1, No. 1 (2018): 13-23. 
according to Hajerni et al. in his research article as published in the Equilibrium Journal of Sociology Education Vol 3, No. 2 November 2016 states that economic factors and situational factors are factors that influence the emergence of Pak Ogah phenomenon. However, the emergence Pak Ogah phenomenon occurred in Indonesia is not only due to economic and situational factors, but also the legal substance, legal structure, and the legal culture of the Indonesian people.

The study illustrates the gap between das sollen and das sein. In das sollen, the guarantee for legal protection for the community is regulated in our constitution. However, the guarantee for legal protection is not received directly by the people, especially by Pak Ogah. Pak Ogah has not received a guarantee from the state in regulating road traffic. Such protection is in the form of guarantees if there are accidents experienced by road users caused by Pak Ogah when managing traffic order. In addition, legal protection is also non-existent, especially related to the guarantee of safety if Pak Ogah experienced an accident when regulating traffic order. The research flow of this study is presented in the chart below:

\begin{abstract}
Article 28D paragraph 1 of the 1945 Constitution of the Republic of Indonesia, Indonesian citizens have the right of recognition, guarantees, protection, and legal certainty that is just and equal treatment before the law.
\end{abstract}

There needs to be a juridical regulation of the existence of Pak Ogah especially in terms of the safety of Pak Ogah androad users

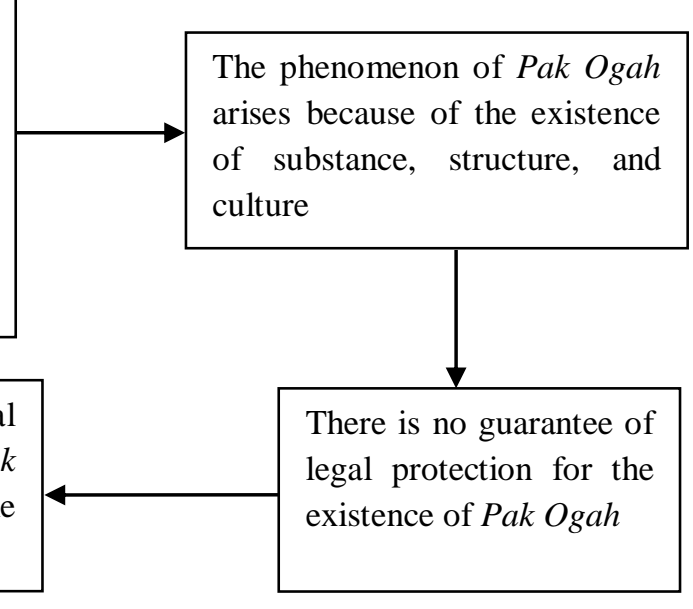

After knowing the research flow above, the following gap will be explained to make the reader understand the further explanation of the author. The gap associated with the phenomenon of Pak Ogah is presented in the chart below: 


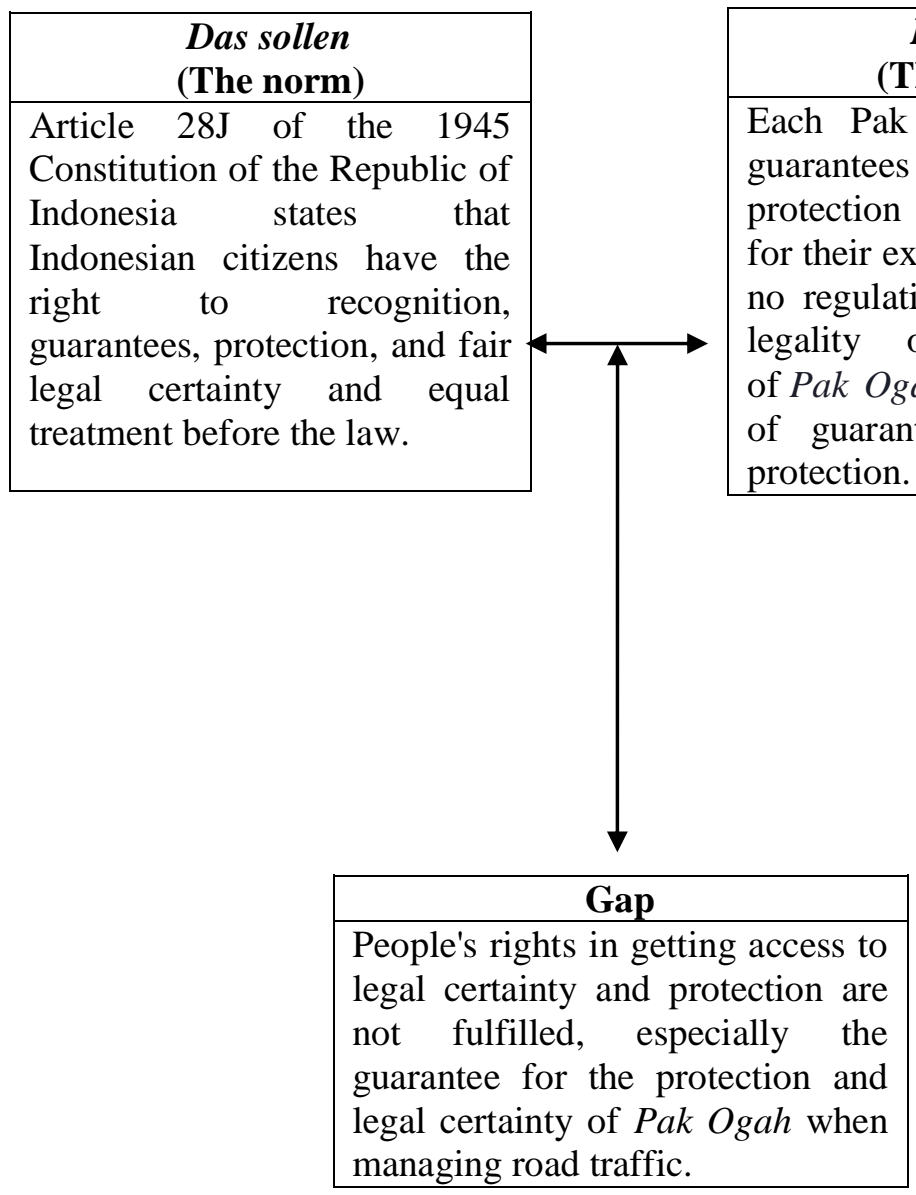

\section{Das sein \\ (The reality)}

Each Pak Ogah still bears for legal rotection and legal certainty or their existence. It is due to gulations governing the $h$ and the absence work safety

(a)

\begin{tabular}{l} 
Problem Formulation \\
\hline What is the factor that \\
influences the emergence \\
of the phenomenon of Pak \\
Ogah? \\
What are the legal \\
problems with the \\
existence of Pak Ogah?
\end{tabular}


Based on the description above, the authors assume that this research is highly important to perform. Problem identification focuses on questioning what issues are the factors that emerge the phenomenon of Pak Ogah and what is the problem with the existence of Pak Ogah. The identification is intended so that we can discover the factors that influence the emergence of Pak Ogah and the problems that arise from the phenomenon. By doing so, it is hoped that this research can provide constructive advice and input for stakeholders to resolve the problem of the existence of Pak Ogah in Indonesia.

Research on the phenomenon of Pak Ogah was conducted by Hajerni et al. in his research article as published in the Equilibrium Journal of Sociology Education Volume 3, No. 2 November 2016 with the title Persepsi Masyarakat terhadap Keberadaan Pak Ogah (Public Perceptions on the Existence of Pak Ogah). The results of research conducted by Harjeni, Nursalam et al. show that the presence of Pak Ogah arises due to situational and economic factors. However, in this study, the author will discuss and view the phenomenon of the emergence of Pak Ogah not only through economic and situational factors, but also other factors such as legal substance, legal structure, and legal culture. ${ }^{10}$

\section{B. Discussion}

\section{Factors Influence the Emergence of Pak Ogah Phenomenon}

The emergence of the phenomenon of Pak Ogah in this discussion will be analyzed using the legal system theory proposed by Lawrence M. Friedman. So in this discussion, the emergence of the Pak Ogah phenomenon is caused by factors, i.e., a legal substance, legal structure, and the legal culture of Indonesian society. The Pak Ogah problem arises because there are problems regarding road traffic management issues. Road traffic management has been substantially regulated in Law Number 22 the Year 2009 Concerning Road Traffic and Transportation, with a legal structure namely the Police as an institution that regulates and implements Law Number 22 the Year 2009 Concerning Road Traffic and Transport. The existence of substance and structure is intended to create an orderly legal culture in Indonesian society in traffic. But in fact, some problems result in a desynchronisation between substance, structure, and legal culture, and result in the emergence of the Pak Ogah phenomenon in Indonesia. The above problems can be analyzed as follows:

\footnotetext{
${ }^{10}$ Nursalam, and Muhammad Akhir, "Persepsi Masyarakat Terhadap Eksistensi Pak Ogah," Equilibrium: Jurnal Pendidikan Sosiologi 3, No. 2 (2015): 223-231. 


\section{a. Legal Substance}

The problem with the emergence of the phenomenon Pak Ogah can be seen from the context of the substance of the law. In this case, how Law Number 22 Year 2009 concerning Traffic and Road Transportation regulates traffic problems in Indonesia. Law Number 22 Year 2009 concerning Road Traffic and Transportation, article 256 states that: "Communities have the right to participate in the operation of Road Traffic and Transportation." The role of the community in organizing traffic and road transportation is emphasized again in article 256 paragraph (2), namely the role of the community in terms of:

1) Monitoring and maintaining Security, Safety, Order, and Continuity of road traffic and transportation;

2) Input to the guiding and implementing agency of Traffic and Road Transportation at the central and regional levels in improving regulations, guidelines, and technical standards in the area of Road Traffic and Transportation;

3) Opinions and considerations to the Traffic Management and Road Traffic and Transportation agencies at the central and regional levels on the activities of Traffic and Road Transportation which cause environmental impacts; and

4) Support for the implementation of Traffic and Road Transportation.

Thus, the problem of the emergence of the phenomenon of Pak Ogah in Indonesia when viewed from the substance of the law. In this case, the emergence of the phenomenon of Pak Ogah is due to the Law which becomes a legal substance that has given the community access to participate in regulating traffic order, that is, as mentioned in articles 256 and 256 paragraph (2) letter a.

\section{b. Legal Structure}

The emergence of the phenomenon Pak Ogah is also caused by factors of legal structure. In this context, the legal structure is a police institution that is given the duty and authority by the Act to enforce and regulate traffic based on what has been regulated in Law Number 22 Year 2009 concerning Traffic and Road Transportation. However, in reality, the Indonesian National Police experienced obstacles in enforcing Law Number 22 Year 2009 concerning Road Traffic and Transportation. The obstacle was in the form of a lack of police personnel to manage the traffic that was scattered in several big cities on a continuous road. This limited personnel is then utilized by the community to participate in managing road traffic.

\section{c. Legal Culture}

The emergence of Pak Ogah is also caused by the culture of Indonesian people who tend to be disorderly in traffic. It has resulted in people needing road regulators such as Pak Ogah. The existence of Pak Ogah is also 
supported by the culture of giving from the people of Indonesia. The community or road users always give tips or rewards to Pak Ogah who helps regulate vehicle traffic. It is shown that the community has indirectly accepted the existence of Pak Ogah in managing road traffic.

\section{Problems of the existence of Pak Ogah}

The community can accept the existence of Pak Ogah. It can be proven by a large number of people who provide rewards for services provided by Pak Ogah in regulating road traffic activities. However, the existence of Pak $\mathrm{Ogah}$ as a regulator of the road is at risk of causing problems that can threaten the safety of both road users and Pak Ogah. Based on the results of interviews and findings in the field, there are 2 (two) problems with the existence of Pak Ogah, these problems include:

\section{a. There is No Guarantee of Legal Protection for Pak Ogah or Road Users If there is an Accident Caused by Traffic Management by Pak Ogah}

The absence can see unregulated guarantees for legal protection on the existence of Pak Ogah in regulating road traffic of legal rules governing the existence of Pak $\mathrm{Ogah}$ as part of the community who participated in managing traffic order. The state has recognized the existence of Pak Ogah in legality, by Article 256 and 256 paragraph (2) of Law Number 22 the Year 2009 concerning Traffic and Road Transportation, which states that the public can participate in managing road traffic activities.

Unregulated guarantees for legal protection will result in material and immaterial losses received by either Pak Ogah or road users in the event of an accident resulting from his/her negligence in regulating traffic order. Unregulated guarantees of legal protection for Pak Ogah when managing road traffic will allow him/her to be prosecuted as the guilty party due to his/her negligence in regulating road traffic order. It is considered unfair, considering that road arrangements made by Pak Ogah do not only cause road traffic accidents. There are other factors such as driver factors that deliberately violate traffic signs or drive vehicles at high speed by ignoring the signs and cues from Pak Ogah that endanger themselves and others. ${ }^{11}$

The absence of guarantees of legal protection from the state against Pak Ogah is also very contrary to the provisions contained in the 1945 Constitution of the Republic of Indonesia Article 28 D paragraph 1 which states that Indonesian citizens have the right of recognition, guarantee, protection, and legal certainty. Considering that Pak Ogah's services in road management are urgently needed, it is fitting for the state of being present by

${ }^{11}$ Marsaid, M. Hidayat Ahsan, "Faktor Yang Berhubungan Dengan Kejadian Kecelakaan Lalulintas Pada Pengendara Speda Motor Diwwilayah Polres Kabupaten Malang," Jurnal Ilmu Keperawatan 1, No. 2 (2013): 98-112. 
providing legal guarantees to Pak Ogah and road users in the event of an accident caused by Pak Ogah's road management activities. In addition, the state also needs to be present to provide training on technical road traffic management for Pak Ogah. It is handy for creating a sense of security for road users.

\section{b. There is No Guarantee of Work Safety if Pak Ogah has an Accident When Regulating Traffic Order}

His work safety guarantee does not accompany the presence of Pak Ogah. The safety of Pak Ogah when managing road traffic is only personal responsibility, so that if there is an accident resulting in injuries to Pak Ogah, then everything has become a risk imposed on himself. Pak Ogah as citizens has the right to guarantee and safety from the state. Their safety must be considered given their existence that has been recognized by the state. Pak Ogah safety in managing road traffic is part of the responsibility of the state in providing social security for its citizens.

Social security is a human right. This affirmation is explicitly stated in Article 22 of the Universal Declaration of Human Rights (UDHR) which was ratified by the Indonesian government in 1998 through TAP MPR NO XVII/MPR/1998. Article 22 of the UDHR reads: "Everyone, as a member of society, has the right to social security and is entitled to realization, through national effort and international co-operation and in accordance with the organization and resources of each State, of the economic, social and cultural rights indispensable for his dignity and the free development of his personality". The assurance of the people as rights holders on social security is also mentioned in Article $28 \mathrm{H}$ paragraph 3 of the 1945 Constitution. Social security, therefore, is one of the constitutional rights of citizens which must not be violated. Article $28 \mathrm{H}$ paragraph 3 of the 1945 Constitution reads: "Every person has the right to social security that enables the development of oneself as a whole with dignified human beings."

\section{Conclusion}

Based on the discussion above, it can be concluded that the existence of Pak Ogah today arises from various factors that are not caused solely by economic and situational factors as mentioned by the previous research. The problem of the existence of Pak Ogah who appears as a social reality needs to be viewed comprehensively, including the need to be examined in terms of substance, structure, and culture following the theory of the operation of law as stated by Lawrance M Fridmen. In one hand, regulation related to the existence of Pak Ogah cannot be found in the positive law in Indonesia. On the other hand, however, the lack of road traffic regulator caused the phenomenon of Pak Ogah to be accepted in the community.

The existence of Pak Ogah emerges as a social reality that brings new problems. The problem is related to the absence of a guarantee of legal 
protection for $P a k O g a h$ or road users if there is an accident caused by traffic arrangements made by Pak $\mathrm{Ogah}$ as well as guarantee for work safety if $\mathrm{Pak}$ Ogah had an accident when managing traffic order. This, if left unchecked, will eventually damage the community's rights (the rights of Pak Ogah and the road users) of guarantee of legal certainty and protection. These are the human rights which regulated in the 1945 Constitution of the Republic of Indonesia as the highest law in Indonesia.

This study suggest that the government not only recognises the existence of Pak Ogah as stipulated in the Traffic Act but also guarantees the legal protection of Pak Ogah or road users if there are accidents caused by traffic arrangements made by Pak Ogah as well as a guarantee for work safety if Pak Ogah has an accident when managing traffic order. It is the duty and obligation of the state to guarantee the welfare of its people.

\section{References}

Agus, Dede. "Perkembangan Pengaturan Jaminan Sosial Tenaga Kerja Dalam Rangka Perlindungan Hukum Buruh/Pekerja." Fiat Justisia: Jurnal Ilmu Hukum 8, No. 1 (2014): 55-56. https://doi.org/10.25041/fiatjustisia.v8no1.286.

Albi, Anggito, Setiawan Johan. Metodologi Penelitian Kualitatif. Sukabumi: Jejak, 2018.

Amin, Muryanto. "Konsep Negara Kesejahteraan dari Waktu ke Waktu." POLITEIA 3, No. 2 (2011).

Asri, Dyah Permata Budi. "Perlindungan Hukum Preventif Ekspresi Budaya Tradisional di Daerah Istimewa Yogyakarta Berdasarkan UndangUndang No 28 tahun 2014 Tentang Hak Cipta." Journal of Intelectual Property 1, No. 1 (2018): 13-23.

Fauzan, Encik Muhamad. "Fungsi Sosiologis UUD 45 dalam Memenuhi Hak-Hak Dalam Masayarakat." Jurnal Masalah-Masalah Hukum 42, No. 3 (2013).

Hamidah, Upik. "Peran Kecamatan Sebagai Perangkat Daerah Dalam Pelayanan Pertanahan (Studi pada Kecamatan Tanjung Karang Timur)." Fiat Justisia: Jurnal Ilmu Hukum 5, No. 2 (2012). https://doi.org/10.25041/fiatjustisia.v5no2.57.

Hidayat, Marsaid M., Ahsan. "Faktor Yang Berhubungan Dengan Kejadian Kecelakaan Lalulintas Pada Pengendara Speda Motor di wilayah Polres Kabupaten Malang." Jurnal Ilmu Keperawatan 1, No. 2, (2013): 98-112.

Listyana, Rohmaul, Yudi Hartono. "Presepsi dan Sikap Masyarakat Terhadap Penanggalan Jawa Dalam Penentuan Waktu Pernikahan." Jurnal Agastya 5, No. 1 (2015). 
Nursalam, and Muhammad Akhir. "Persepsi Masyarakat Terhadap Eksistensi Pak Ogah." Equilibrium: Jurnal Pendidikan Sosiologi 3, No. 2 (2015).

Pasek, Diantha Made. Metodelogi Penelitian Hukum Normatif dalam Justifikasi Teori Hukum. Jakarta: Prenadamedia Grup, 2016.

Plaituka, Solidman Bertho. "Constitusional Complaint Dalam Rangka Penegakan Hak Asasi Manusia di Republik Indonesia." Jurnal Media Hukum 23, No. 1 (2016): 110-120.

Ridlwan, Zulkarnain. "Negara Hukum Indonesia Kebalikan Nachtwachterstaat." Fiat Justisia: Jurnal Ilmu Hukum 5, No. 2 (2012). https://doi.org/10.25041/fiatjustisia.v5no2.56.

Ridwan, HR. Hukum Administrasi Negara. Jakarta: Rajawali Pers, 2011.

Satjipto, Raharjo. Ilmu Hukum. Bandung: Citra Aditya Bakti, 2000.

Soerjono, Soekanto. Pengantar Penelitian Hukum. Jakarta: UI Perss, 2007. 
